\title{
Putative involvement of endodontic treatments in maxillary sinus aspergillosis
}

\author{
Posibile implicaţii ale tratamentelor endodontice în \\ aspergiloza sinusurilor maxilare
}

\author{
Paula Perlea' ${ }^{1}$ Anca Temelcea² ${ }^{2}$ Alexandru Andrei Iliescu ${ }^{3}$ \\ ${ }^{1}$ Facultatea de Medicină Dentară, Universitatea de Medicină şi Farmacie „Carol Davila“, \\ Bucureşti, România \\ ${ }^{2}$ Facultatea de Medicină Dentară, Universitatea de Medicină şi Farmacie, Craiova, România \\ ${ }^{3}$ FMAM Tehnică Dentară, Bucureşti, România
}

\begin{abstract}

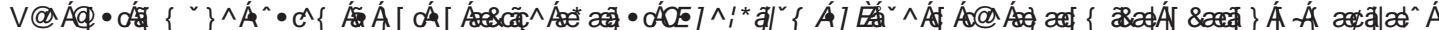

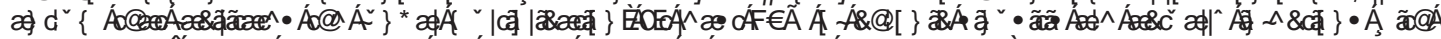

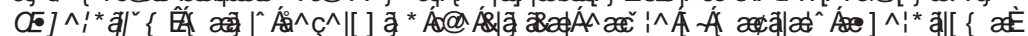

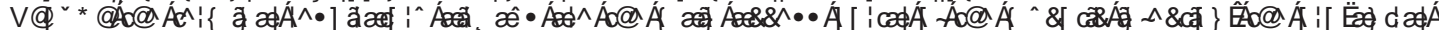

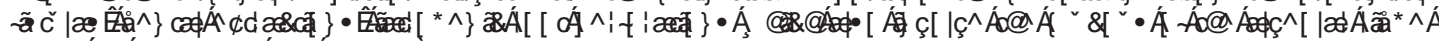

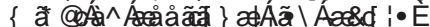

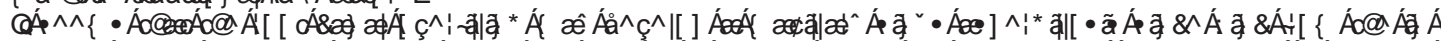

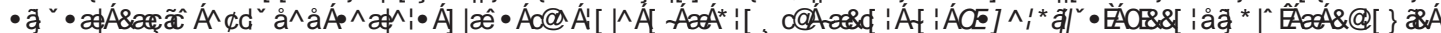

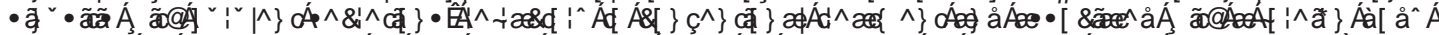

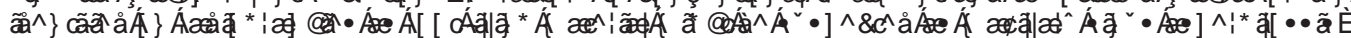

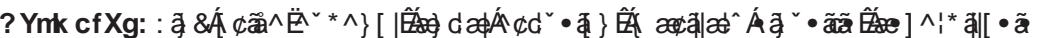

\section{REZUMAT}

Din cauza locaţiei anatomice, în formele clinice de aspergiloză care afectează sinusurile maxilare, sistemul imun acţionează mai greu şi ciuperca se multiplică mai uşor. De remarcat că în cel puţin $10 \%$ dintre sinuzitele cronice întâlnim o infecţie cu Aspergillus, de regulă sub forma aspergilomului.

În afara căii de acces aeriene, care deţine incidenţa maximă, o altă posibilitate de infectare sinusală cu specia $A$. fumigatus este oferită de manoperele terapeutice incorect conduse complicate cu o cale de comunicare oroantrală, cum ar fi extracţia dentară sau căile false radiculare din tratamentele de canal, când se ajunge la perforarea mucoperiostului crestei alveolare.

Se pare că aspergiloza sinusurilor maxilare cauzată de obturaţiile de canal cu depăşire este favorizată de prezenţa zincului în cimenturile de sigilare, unul dintre metalele grele care constituie factori de creştere pentru ciupercile din genul Aspergillus. Pe fondul unei obturații de canal cu extrudarea cimentului în sinusul maxilar, ori de câte ori ne confruntăm cu o sinuzită maxilară refractară la tratament sau recidivantă, cu secreţii purulente, este bine să ne gândim la o posibilă aspergiloză, examenul radiologic fiind de mare utilitate.

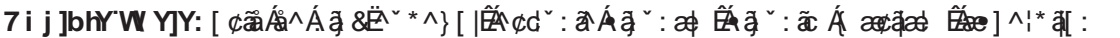

\section{INTRODUCERE}

Comparativ cu bolile infecțioase bacteriene sau virale, multă vreme, incidența micozelor superficiale, ca şi a celor invazive, s-a păstrat la nivel redus, dar în ultimele decenii este în creştere, ca o consecință a tratamentelor cu antibiotice şi imunosupresoare.
Deşi reprezentate preponderent de specii saprofite ale comunităților microbiene din sol, un număr mai restrâns de ciuperci aparține fie florei comensale ale aparatului digestiv, fie florei rezidente ale tegumentelor, care uneori pot căpăta însă un caracter patogen. 
Cea mai frecventă formă clinică de aspergiloză invazivă cauzată de $A$. fumigatus este aspergiloza pulmonară, unde, în mediul cald şi umed al alveolelor pulmonare favorabil acestei ciuperci termofile, conidiile inspirate trec în hife, fie extracelular, fie în endosomii pneumocitelor de tip II. Prin penetrarea ulterioară a mucoasei şi a endoteliului vascular se activează cascada coagulării, care conduce la efecte tisulare locale de tromboză şi infarctare $(1,2)$.

\section{Genul Aspergillus}

Aspergiloza constituie o boală infecțioasă provocată de ciuperci cu răspândire ubicuitară din genul Aspergillus, clasa Ascomycetes, găsindu-se în atmosferă, sol, apă, praf de la demolări de construcții vechi, plante, alimente şi materii organice vegetale sau animale în putrefacție. Pentru om sunt patogene cel mult 20 de specii dintre cele aproape 900 cunoscute.

Agentul patogen cel mai frecvent întâlnit la om în aspergiloza invazivă este specia $A$. fumigatus (80-90\%), secondată de $A$. flavus (5-10\%) şi rareori de $A$. niger (1-5\%), A. terreus ( $1 \%$ ) sau A. nidulans $(3,4)$. De subliniat de asemenea că $A$. fumigatus este de regulă vectorul aspergilozei la indivizii imunocompetenți (4).

Ciupercile din genul Aspergillus au o structură tubular-filamentoasă cu diametrul de 2-4 $\mu \mathrm{m}$, hifele fiind separate. Celulele hife se pot diferenția în conidii, care asigură pătrunderea în organismul uman prin inhalare şi sunt capabile de supraviețuire în medii ostile, iar uneori pot da naştere în micelii la structuri celulare similare blastosporilor şi levurilor $(1,3)$.

Fiind un microorganism saprofit aerob, implicat în reciclarea carbonului şi azotului, dezvoltarea speciei A. fumigatus este în mod firesc favorizată de mediile bogate în oxigen şi de substraturile nutritive bogate în hidrați de carbon din alimente uzuale, precum cartofii şi pâinea.

\section{Patogeneza}

Infectarea are loc de regulă pe cale respiratorie, prin inhalarea sporilor acestei ciuperci larg răspândite în mediul înconjurător, practic câteva sute zilnic, dar nu afectează persoanele sănătoase, cu sistem imunitar eficient, şi nici nu se poate transmite de la un individ la altul sau între om şi animale. $A$. fumigatus prezintă micelii ramificate şi se transmite în aer prin conidiospori verzi-cenuşii, cu dimensiunea de 2-3 $\mu \mathrm{m}$, care supraviețuiesc mai multe luni deoarece rezistă la deshidratare, căldură sau tratamente chimice. Fiind un microorganism termofil, ciuperca poate creşte la temperaturi până la $50^{\circ} \mathrm{C}$, dar sporii rezistă chiar şi la $70^{\circ} \mathrm{C}(2)$.

Creşterea ciupercii pe anumite materiale de construcție duce la elaborarea unor micotoxine, în special a gliotoxinei, care are efect citotoxic şi genotoxic (5). Un alt efect patogen al gliotoxinei constă în perturbarea răspunsului inflamator grație supresiei factorului nuclear $\mathrm{kB}(6)$.

Mecanismul de acţiune imunosupresiv al gliotoxinei se bazează în primul rând pe inhibarea sintezei de superoxizi şi a migrării polimorfonuclearelor neutrofile (7), dar simultan este indusă şi apoptoza macrofagelor (8). Sinteza gliotoxinei este controlată de factorii de transcripţie LaeA şi GliZ. LaeA este, de asemenea, implicat în producerea de metaboliți secundari şi reglarea altor toxine care imprimă virulența ciupercii A. fumigatus (9).

In formele profunde de aspergiloză, invazia tisulară a ciupercii este precedată de elaborarea masivă de elastaze (10), precum metaloproteazele (11), serin (12) şi aspartic proteinaza (13). În multiplicarea ciupercii şi exprimarea virulenței, un rol important pentru A. fumigatus îl are captarea fierului şi azotului din mediul tisular (14).

Privarea metabolismului gazdei de fier, care joacă rolul de cofactor enzimatic, poate avea loc fie prin trecerea ionului feric în ion feros (15), fie prin siderofori, acest din urmă mecanism fiind necesar în expresia virulenței (16). A. fumigatus poate fi întâlnit pe diverse substraturi ce conțin azot, dar numai mediile bogate în acest element chimic contribuie la creşterea virulenței sale (17).

De reținut că $A$. fumigatus poate acționa şi antimitotic prin elaborarea unei serii de alcaloizi indolici care stau la baza producerii unei medicații anticanceroase, precum spirotriprostatina B (18).

\section{Posibila inducere a aspergilozei sinusurilor maxilare prin tratamente endodontice}

În zona aparatului dento-maxilar, aspergiloza afectează de regulă cavităţile sinusale, unde sistemul imun acţionează mai greu şi ciuperca se multiplică mai uşor (19). De remarcat că, în cel puțin $10 \%$ dintre sinuzitele cronice, întâlnim o infecție cu 
Aspergillus, de regulă sub forma aspergilomului (3). Ori de câte ori ne confruntăm cu o sinuzită maxilară refractară la tratament sau recidivantă, cu secreții purulente, este bine să ne gândim la o posibilă aspergiloză, examenul radiologic fiind de mare utilitate (4).

O altă cale de acces sinusal al ciupercii este oferită de manopere terapeutice incorect conduse care creează o cale de comunicare oro-antrală, cum ar fi extracția dentară, mai frevent, dar chiar şi căile false radiculare din tratamentele de canal (lărgiri, dezobturări, lăcaşuri pentru pivoți) când ajung să perforeze şi mucoperiostul alveolar (4).

Aparent la indivizii sănătoşi, principala cauză aspergilozei sinusurilor maxilare ar fi obturația de canal care penetrează prin materialele sale (ciment de sigilare, con de gutapercă sau argint) în cavitatea sinusală în urma depăşirii apexului rădăcinii dintelui tratat endodontic $(20,21)$. Amalgamul de argint este de asemenea incriminat $(21,22)$.

Ciuperci filamentoase au fost izolate şi în canalele radiculare infectate $(18,23)$, fiind considerate, alături de alte microorganisme reziduale, drept responsabile de eşecul tratamentelor endodontice (23). Un studiu microbiologic a demonstrat prezența ciupercilor filamentoase la $28,3 \%$ dintre pacienții cu gangrenă pulpară. De remarcat că, în acest lot de studiu de 60 cazuri, genul Aspergillus (A. ustus, A. granulosus, A. niger, A. sydowii) a atins chiar $41 \%$ din numărul total de ciuperci filamentoase izolate (23).

Se pare că aspergiloza sinusurilor maxilare cauzată de obturațiile de canal cu depăşire este favorizată de prezența zincului în cimenturile de sigilare, unul dintre metalele grele care constituie factori de creştere pentru ciupercile din genul Aspergillus $(3,18,24-26)$. Mai rar în acelaşi context etiologic ar fi incriminați şi sigilanții cu formaldehidă (20), deşi este greu de delimitat rolul acesteia, întrucât în compoziția sigilanților respectivi de regulă intră şi oxidul de zinc. Totuşi, formaldehida poate acționa şi de sine stătător prin necroza indusă în țesuturile periapicale în caz de depăşire (25).

Reacția inflamatorie de corp străin declanşată de pătrunderea materialelor de obturație de canal în sinusul maxilar poate crea un mediu favorizant colonizării ciupercilor, iar zincul, pe lângă intervenția în metabolismul acestora, facilitează depunerea fosfaților de calciu şi crearea unui situs de depunere a sporilor de Aspergillus prin paralizia mucociliară şi întreținerea hiperemiei mucoasei sinusale $(21,27)$.

Totuşi, alte studii au demonstrat proprietăţile antifungice față de Aspergillus ale multor cimenturi de sigilare precum AH26, Sealapex, pasta Grossman, inclusiv a cimentului clasic oxid de zinc-eugenol. Pe de altă parte, trebuie reținut că efectul fungicid şi fungistatic al eugenolului din diversele cimenturi de sigilare se reduce în timp o dată cu instalarea prizei sigilantului $(3,15,22,28)$. În acest context, pare atractivă şi ipoteza posibilităţii pătrunderii în cavitatea sinusală a unui ciment de sigilare cu oxid de zinc deja contaminat cu spori de Aspergillus din mediul înconjurător ca vector în declanşarea aspergilozei sinusurilor maxilare $(3,22)$.

Dată fiind patologia sinusală care se poate declanşa de la dinții ai căror apexuri se află la foarte mică distanță în contact anatomic cu podeaua sinusului maxilar, fie prin evoluția parodontitelor apicale cronice, fie prin extruzia cimenturilor de sigilare pe bază de oxid de zinc în obturațiile de canal cu depăşire, se recomandă îndepărtarea chirurgicală imediată a excesului de material endodontic extrudat în sinus pentru evitarea unei aspergiloze sinusale întreținute de zincul ce servește ca factor de creştere ciupercilor genului Aspergillus.

\section{Mențiune}

Toți autorii au contribuție egală în realizarea acestui articol.

Conflict of interest: none declared Financial support: none declared

\section{BIBLIOGRAFIE}

1. Ben-Ami R., Lewis R.E., Kontoyiannis D.P. Enemy of the (immunosuppressed) state: an update on the pathogenesis of Aspergillus fumigatus infection.

Br J Haematol 2010; 150(4):406-417.

2. Mohindra S., Mehta R., Bal A. ABPA concomitantly occuring with invasive sinus aspergillosis: a short report on two

patients. Indian J Otolaryngol Head Neck Surg 2014; 66(Suppl 1):S329-S333.

3. Khongkhunthian P., Reichart P.A. Aspergillosis of the maxillary sinus as a complication of overfilling root canal material into the sinus: report of two cases. J Endod 2001; 27(7):476-478. 
4. Peral-Cagigal B., Redondo-Gonzalez L.M., VerrierHernandez A. Invasive maxillary sinus aspergillosis: a case report succesfully treated with voriconazole and surgical debridement. J Clin Exp Dent 2014; 6(4):e448-451.

5. Nieminen S.M., Kärki R., Auriola S., Toivola M., Laatsch H., Laatikainen R., Hyvärinen A., Von Wright A. Isolation and identification of Aspergillus fumigatus mycotoxins on growth medium and some building materials. Appl Environmental Microbiol 2002; 68(10):4871-4875.

6. Gardiner D.M., Waring P., Howlett B.J. The epipolythiodioxopiperazine (ETP) class of fungal toxins: distribution, mode of action, functions and biosynthesis. Microbiology 2005; 151(Pt4):1021-1032.

7. Spikes S., Xu R., Nguyen C.K., Chamilos G., Kontoyiannis D.P., Jacobson R.H. et al. Gliotoxin production in Aspergillus fumigatus contributes to host-specific differences in virulence. $\mathrm{J}$ Infect Dis 2008; 197(3):479-486.

8. Kamei K., Watanabe A. Aspergillus mycotoxins and their effect on the host. Med Mycol 2005; 43(Suppl 1):S95-99.

9. Perrin R.M., Fedorova N.D., Bok J.W., Cramer R.A., Wortman J.R., Kim H.S. et al. Transcriptional regulation of chemical diversity in Aspergillus fumigatus by LaeA. PLoS Pathog 2007; 3(4):e50.

10. Kothary M.H., Chase T., Macmillan J.D. Correlation of elastase production by some strains of Aspergillus fumigatus with ability to cause pulmonary invasive aspergillosis in mice. Infect Immun 1984;43 (1):320-325.

11. Markaryan A., Morozova I., Yu H., Kolattukudy P.E. Purification and characterization of an elastinolytic metalloprotease from Aspergillus fumigatus and immunoelectron microscopic evidence of secretion of this enzyme by the fungus invading the murine lung. Infect Immun 1994; 62(6):2149-2157.

12. Reichard U., Büttner S., Eiffert H., Staib F., Rüchel R. Purification and characterisation of an extracellular serine proteinase from Aspergillus fumigatus and its detection in tissue. J Med Microbiol 1990; 33(4):243-251.

13. Lee J.D., Kolattukudy P.E. Molecular cloning of the cDNA and gene for an elastinolytic aspartic proteinase from Aspergillus fumigatus and evidence of its secretion by the fungus during invasion of the host lung. Infect Immun 1995; 63(10):3796-3803.

14. Dagenais T.R., Keller N.P. Pathogenesis of Aspergillus fumigatus in invasive aspergillosis. Clin Microbiol Rev 2009; 22(3):447-465.

15. Haas H. Molecular genetics of fungal siderophore biosynthesis and uptake: the role of siderophores in iron uptake and storage. Appl Microbiol Biotechnol 2003; 62(4):316-330.
16. Schrettl M., Bignell E., Kragl C., Joechl C., Rogers T., Arst H.N. et al. Siderophore biosynthesis but not reductive iron assimilation is essential for Aspergillus fumigatus virulence. $J$ Exp Med 2004; 200(9):1213-1219.

17. Panepinto J.C., Oliver B.G., Amlung T.W., Askew D.S., Rhodes J.C. Expression of the Aspergillus fumigatus rheb homologue, rhbA, is induced by nitrogen starvation. Fungal Genet Biol 2002; 36(3):207-214.

18. Cui C.B. Spirotryprostatin B, a novel mammalian cell cycle inhibitor produced by Aspergillus fumigatus. J Antibiot 1996; 49(8):832-835.

19. Agarwal M.K., Shukla P.K. Aspergillosis of the maxillary sinus. IJO \& HNS 1998; 50(1):43-45.

20. Giardino L., Pontieri F., Savoldi E., Tallarigo F. Aspergillus mycetoma of the maxillary sinus secondary to overfilling of a root canal. J Endod 2006; 32(7):692-694.

21. Urs A.B., Singh H., Nunia K., Mohanty S., Gupta S. Post endodontic aspergillosis in an immunocompetent individual. J Clin Exp Dent 2015;784):e535-539.

22. Machida M., Asai K., Sano M., Tanaka T., Kumagai T. et al. Genome sequencing and analysis of Aspergillus oryzae. Nature 2005;438(7071):1157-1661.

23. Gomes C., Fidel S., Fidel R., de Moura Sarquis M.I. Isolation and taxonomy of filamentous fungi in endodontic infections. J Endod 2010;36(4):626-629.

24. Abad A., Fernández-Molina J.V., Bikandi J., Ramírez A., Margareto J., Sendino J., Hernando F.L., Pontón J., Garaizar J., Rementeria A. What makes Aspergillus fumigatus a successful pathogen? Genes and molecules involved in invasive aspergillosis. Rev lberoameric Micolog 2010;27(4):155-182.

25. Guivarc'h M., Ordioni U., Catherine J.H., Campana F., Camps J., Bukiet F. Implications of endodontic-related sinus aspergillosis in a patient treated by infliximab: a case report. J Endod 2015; 41(1):125-129.

26. Tanasiewicz M., Bubilek-Bogacz A., Twardawa H., Skucha-Nowak M., Szklarski T. Foreign body of endodontic origin in the maxillary sinus. J Dent Sci 2017; 12:296-300.

27. Nierman W.C., Pain A., Anderson M.J., Wortman J.R., Kim H.S. et al. Genomic sequence of the pathogenic and allergenic filamentous fungus Aspergillus fumigatus. Nature 2006; 438(7071):1151-1156.

28. Schrettl M., Bignell E., Kragl C., Sabiha Y., Loss O., Eisendle M. et al. Distinct roles for intra- and extracellular siderophores during Aspergillus fumigatus infection. PLoS Pathog 2007; 3(9):1195-1207. 